\title{
CHRYSTOLOGICZNA KONCENTRACJA W NAUCE ŚW. AMBROŻEGO Z MEDIOLANU
}

Wielu autorów sadz1, ze św.Ambrozy z Mediolanu, ulegajacy zawsze wpływom teologil wschodntej, nie posiadal wrasnej, oryginalnej doktryny teologicznej ${ }^{1}$. Nie tylko bowiem 1ch zdaniem etreszczaz calymi partlami czytane aktualnie pisma Hipolita, Orygenesa, Filona czy Bazylego, ale nawet enująo wasne refleksje pozostawaz zasadniczo wamach koncepcj1 narzuconych przez danego autora. Tymczasem, mimo tego braku samodzielnośo1, mozna podzimiac talent Ambrozego przyewajaniu laciúskiej umysłowośc1 osiagnięć teologil wschodniej. Jeśl1 nawet ustępuje Kapadocczykom 1 Aleksandryjczykom v bystrośc1 1 oryginalnośo1 poglądów, to przewyzsza $1 \mathrm{ch}$ niewatpliwie wasnośo1 wykładu 1 zastosowantach moralno-pastoralnych. Takzo dzięki gwej nauce został zaliczony poczet wielkich ojców Kościola Zachodniego. Sledzac jego pisma worzadku chronologicznym zauwazyć mozna, Jak wypracowywał oryginalna doktrynę o zyciu duchowym ozłowieka, w kórej lstotaym rysem jest chrystocentrzym.

Zasadność podjęc1a zagadnienta chrystocentryzmu wauce ów. Ambrozego wynika z niejednolitości ocen w tej materi1. Jedni bowiem autorzy głosza, zo wéród 0joów na Zachodzie chrystocentryzm charakteryzujo przede wszystkim teologie św.Augustyna ${ }^{2}$, da kárego nio Istnieje inna tajemnica Boga, Jak tylko Chrystus ${ }^{3}$, nie wopominajac nio o śn.Ambrozym, chociaz ex professo zajmuja sie chrystocentryzmem. Inni zaś zwłaszcza w swolch podrecznikach 1 artykułach encyklopedyoznyoh wyraźnie akcentuja chrystocentryzm jako najbardziej charakterystyozna ceche teologil tegoz 0Jca Koścloła. Mófia, ze 0so-

1 Por M, Simonett1, Ambrogio d1 Milano, B1bliotheca Sanctorum, Roma 1961, t.1,977; E.Cataneo, Milan et le Milanais, DS VII 2150; A.Santorsici, Odkupienie człowieka w nauce św.Ambrozego, w: Drogi zbawienta, praca zbiorowa pod red. H. Przybylskiego, Poznań 1970,364 .

2 E.Koped, Znaozenle chrystologicznej koncentracji w teologil wspólczesnej, w: Chrystooentryzm w toologi1, praca zbiorowa pod red. E.Kopola, Lublin 1977, 9; A.Nosol, Chrystocentryzm, EK III 297 .

3 Por. Epistola 187,94. 
ba Chrystusa stanowi w jego nauce podstawę 1 źródło moralnośc1 4 . Warto więc zbadać, Jakiej mierze te wypowiedzi ga prawdziwe. Jakie sa więc istotne ldee chrygtologicznej koncentracji w teologil sw.Ambrozego? Wydaje się, ze moźna je sprowadzic do nastepujących twierdzeń: Chrystus jest Bogiem 1 czkowiekiem, Jeden o dwóch naturach; jest on nauczycielem moralnośc1, który siobie stawia za przykład; jest sprawca kazdej cnoty; oblubleńcem duszy; z Nim rozmawlamy, gdy się modlimy; jest on dla nas wszystkim.

1. "Et Deum Christum et hominem esse credamus unum in utroquen

Już K.Schwerdt ukazal, Jak wielki byl autorytet św.Ambrozego w chrystologil doby Soboru Ereskiego 1 Chalcedońkiego ${ }^{6}$. Istotnie, powołujace sie na jego autorytet, ojcowie oborowi uczyli, ze nie mozna przeczyó ani jedności Boga 1 człowieka w Jezusio Chrystusio, ant tez Jego prawdziwego bóstwa 1 pełnego czlowieczeństwa?. Ambrozy staral sie pogodzić chrygtologle ozkoky aleksandryjokiej 1 szkoły antiocheńskiej, których słowniotwo w IV w. było mało ścisłe. Aż do Soboru Chalcedońskiego nie było okrélenta powszechnie przyJętego na oznaczenie równoczénie jednośol Chrystusa 1 odrębnośc1 natur, boskiej 1 ludzk1ej. Byzo to przyczyna wielkioh 1 zawiłych sporów chrystologioznych.

Nauka chrystologiczna f́r.Ambrozego dojrzewała wlimacio zmagaí z ówczesnymi herezjam1. Z niespozyta energla polemizowaz w swolch dzlelach ezczególnie z nauką arian, przeciwko ktérym wystapil na synodzio $w$ Akwilel /381 r./. N1e zawahal sieg rómniez podjać walki z cesarzowa Justyna, zwlaszcza kiedy poparła arian w spa-

4 L.Małunowdczówna, Ambrozy św. bp Mediolanu, EK I 415; F.Cayro, Précie de la patrologie, Paris 1930, t.1,530; G.Bardy, Ambroise Salnt, DS I 428; Powołanie chrześc1jańskie. Zarys teologil moralnej. Praca zbiorowa, t.1: Istota powołania ohrześc1jańskiego, Opole $1978^{2}, 34$.

5 Expositio Evangel11 secundum Lucam $X 3, \operatorname{SCh} 52,157, \operatorname{PSP} 16,407$.

6 K.Schwerdt, Studien zur Lehre des helligen Ambrosius von der Person Christ1, Freiburg 1937, 27-34.

7 Acta Concil11 Ephesent, ed. E.Sohwartz, I 4,2, 9.122; Acta Conc1111 Chalcedonensis, ed. E.Schwartz, II 4, s.123. 
w1e oddania im przez katolików jednej z bazylik w mé́o1e. Ambrozy zwalczał takze zwolenników Apolinarego z Laodyce1 /310-390/. którzy kwestionowali pełnie ludzkiej natury Chrystusa. Byz rómniez przeciwnikiem innych herezjl chrystologioznych. Szozególnie " traktatach "De fide" 1 "De Incarnationis Dominicae Sacramento" wystepowal przeciw eunomianom, zwolennikom Pawka z Samosaty, walentynianom 1 stronnikom Bazylidesa. Wraśnte kontecznośó walki z tymi herezjami myznaczyła zdecydowany ohrystocentryzm Biskupa medi olańskiego.

Sw.Ambrozy od początku swej działalnoścl biskupiej nauczax, te Chrystus jest prawdziwym Boglem 1 prawdzimym ozłowlekiem. Bóstwa Chrystusa broniz niemal na kazdej stronie dziekka "De eide", zaznaczajac, ze Chrystus jest równy we wszygtkim ojou. Jedno jest dzjazanie Jego 1 0joa, Jedna godnób́ 1 jedna natura. Syn 1 0joleo maja to samo bóstwo 8 .

Ambrozy stanal takze obronie prawdziwego ozłowleczeństwa Chrystusa. Sam przyznamaz, ze ozęsto pouozal/frequenter admonui/, 1z Syn Bozy przyjaz ludzkie clako wraz z rozuma dusza ludzka ${ }^{9}$. Wystepujac przecí Fotynowi 1 Apolinaremu z Laodyoe1, Śm.Ambrozy głos1ł, ze Jak pod względem bóstwa, tak równiez pod względem człowieczeństwa nic Chrystusoni nie brakomalo 1 nie moze on uchodzió a ozłowieka niedoskonazego. Syn Bozy jest podobny do nas przez posiadanie rozumnej ludzkiej duszy oraz prawdziwego olaka ${ }^{10}$. Człowieczeństwo zbawiciela rozmazane jest pQ prostu oparciu o nieustannie powtarzany przez. Ambrozego aksjomat: "Tylko to jest sbaw1one, co zostazo przybrane". Chrystus od nas zapozyczyz to, co oflarowuje jako swoje, by od nas otrzymać cene naszego okupu. Motywem Weielenia moze byó wįo nie oo innego, jak przyjęo1e tego olaka, które zgrzeszyło, aby przez nie dokonało sie Odkupienie ${ }^{1}$.

8 De fide I 2,15; II 9,77, PL 16,532,576; De Incarnation1s Dominicae Sacramento 5,35, PL 16,827.

9 Explanatio Symbol1 3, CSEL 73,4, РOK 26, 26.

10 Eplstola 48,5, PL 16,1153; De Inoarnationts Domintoae Sacramento 9, 104, PL 16,843, POK 26,135. 11 De Incarnationis Dominicae Saoramento $6,54156, \mathrm{PL} 16,832$,
POK 26,122. 
Biskup Mediolanu zaznaczał rómniez mocno róznice obu natur w Chrystusie. Wszelkie ich zmieszanie duchu monofizyckim jest wykluczone. Jasno wiec Ambrozy przedkładał swolm siuchaozom 1 ozytelnikom, ze Chrystus posiada jednocześnie bóstwo 1 clało, ze jest Bogiem 1 człowiekiem, jeden o dwóch naturach, ale nie podwójny ${ }^{12}$. z Jego wypowledzl mozna wyprowadzí wnioski o periohorezie 1 wymianie orzekań. Istotnie mówiz on o wspóxprzenikalnosci Bozyoh 0sób, które są odrębne, a mają tozsama naturę 1 ścisłą kyoiowa wspólnotę ${ }^{13}$. Nie posługiwal sie on jeszcze wyrazeniem cormunioatio Idiomatum, ale utrzymyal niezachwianio, ze osobie Słowa Wcielonego nalezy przypisymad zarómno ozyny 1 maécimoścl bóstwa 1 człomeczeŕstwa, Jak 1 uozuola ludzkie.

Sw.Ambrozy głosząc równośb 0jea 1 Syna, mógz tez twierdz16, ze wéród nich nle ma plerwazego, 1 te Chrystus jest wazechmocny. Komentujac Ewangelie wedtug sw.Lukasza, wykzadal czessto te prawde $e^{14}$. Nógł tez twierdzić, ze Syn jest sprawca 1 atwóroq wazystklego, poozątkiem 1 końcem wszystkioh rzeczy, twóroq ozasu 1 stworzycielem nieb108${ }^{15}$. On takze jest wszedzio obecny.

WW Panu Jezusie wazystko zostako stworzone na niobie 1 zlem1, widzialne 1 nlewidzialne, a on jest przed wazystkim1 1 mszystko Nim trwa. Spójrz niebo, tam jest Jezus, patrz na zlem18 - Jezus jost obecny; wstap slowem do nieba; zstap slowem podzlemie, jest tam Jazus. Dzisiaj, gdy to mówio, jest zo mna $\nabla$ tym miejscu, tej chwili. Jé́l1 Armenil mów1 tersz jaki chrzesoljanin, jest tez tam Jezus obeonyilo.

12 De Sacrament1s VI 1,4, CSEL 73,73, POK 26,87; Brposit10 Evangel11 seoundum Luoam X 3 , SCh 62,157 , PSP 16,407.

13 Wypowiedzl Ambrozego dotyozaco perichoresy sebral $K_{0}$ Sohwerdt, dz.oyt., 82-83.

14 Expositio Evangel11 seound um Luoam II 95; $\mathrm{x} 68, \mathrm{SCh} 43,118$; SCh 52,179, PSP 16,94 1430 ; Por. De P1de IV 11, 1401146 , PL 16,644 1645 ; Explanat10 Symbol1 7 , CSEL 73,10, POK 26, 29.

15 De I1de IV 11,155; V 2,30 1 34, PL 16,646,655 i 656; De Myster118 8,46 , CSEL 73,109, POK 26,46; De Inoarnation1s Dominiçae Sacramento 3,26 , PL 16,825 , POK 26,113; Por. F.Saabo, Le rôle de Pila dans la oreation selon saint Ambroisa, "Augustinlanum" 7/1967/258-305.

16 Exposit10 Bvangel11 sooundum Lucam II 13, SCh 45,78, PSP 16,55 . 
Jakie 1 mplikacje ze swej doktryny chrystologicznej wyprowadzał św. Ambroźy? Jakie konsekwencje dla zycia duchowego chrześciJanina wynikaja z Paktu, ze Chrystus jest prawdziwym Bogiem 1 ozłowiekiem? Ten Ojciec Kośoloza jest przede wszystkim moralista. Dlatego tez jego zasadnicza odpowiedź na to pytania brzmi: Jako Bóg Chrystus jest nauczycielem moralnośo, a Jako ozłowiek stawia innym siebie samego za przykład.

2. "Moralis Magister, qui de se coteris praebet exemplum"17

Biskup Mediolanu nie tylko uczy, ze Chrystus jest prawdziwym Bogiem 1 człowleklem, ale takze ukazuje scisły zwiazek miegdzy Wcieleniem a naszym uświęceniem. Syn Bozy "stał sie człowiekiem, by nam utorować droge do nieba" ${ }^{18}$. Ambrozy często posługuje s1e słowem "susceptio", wzorując s1e na Atanazym. Chrystus przyjaz nasze nlemoce, aby natura nasza, słaba dawniej, woparta teraz o Niego, wzmocniła się. Przyjmujac zaś na siebie nature ludzka, udostępnil nam dary swego bóstwa. Kaznodzieja z Mediolanu komentowal to p péknych przeciwstawieniach:

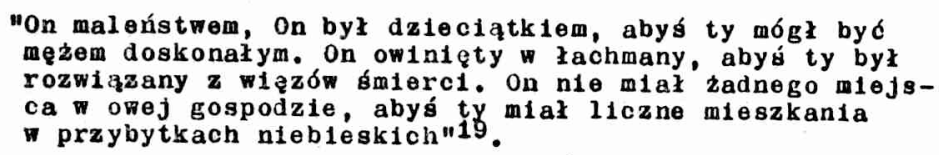

Wywód Ambrozego, choó pełen finezjl retorycznej w obronie kompletności natury ludzkiej zbawiciela, ma owój praktyczny rel1gijno-moralny wydźwięk. Przykładem moze być tekst z jego "Komentarza do Ewangel11 św.Lukaszes

17 Tamże VI 36, SCh 45,241, PSP 16,224.

18 De fide III, 7,50, PL 16,600; Por. Explanat1o Symbol1 6, CSEL 73,9, POK 26,28 .

19 Expositio Evangeli1 secundum Lucam II 41, SCh 45,91, PSP 16,68; Por. De fide IV 12,164, PL 16,648; A.Santorsk1, Odkupiente ozłow1eka w nauce św.Ambrozego, art.cyt. 357 . 
"Naucz sie z tego nakazów pozytecznych dla slobie; przyswój sobie togo rodzaju przykłady. Poznaj, co zamdzieczas swym rodzicom, gdy caytasz, iz Syn od ojca gie nie rózni ant woleg, and dzialantem, ani co do czasu. Chod sa dwie Ogoby, jednakio co do potegi ea jednym. Oezywisc1e, iź ót niobleski. Ojeloo przy rodzeniu syna nie mial

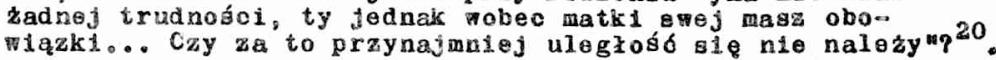

Ambrozy by gicznago, którogo nie mia. czasu zdobyó, gdys njespodzjemanie z katochumena wybano go bisupem. Dlatego z prackonaniem stwierdaz. ze Jeden jost tylko pravdzify Nauczyciel, kifry nde potrzabowal uczyó 18 , aby wszystikich nauczad; Judzio zá́ tego, ozego mają in-

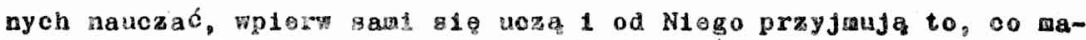
Ja tnnym przekazab. Chrystusa nazywal Ambrozy "nauczyojolem moralnoścx", "nauczycielem onoty", "nauczycielem synowskiej miłośc1"21. Chrysius, obraz 0jca, jebt dla nas wzorem enoty 1 woze nas kaztaktowá wadzug swago wzoru. On przedstawiwszy swoje nakazy caynem poucza, jak jo typezn1s ${ }^{22}$.

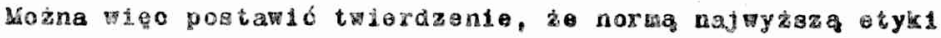

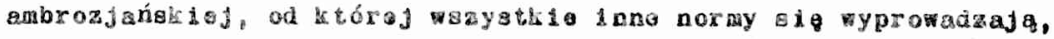
ndo jest jajkés pojgcio abotrakcyjne, locz 0soba Jezuaa Chrygtusa.

N10 w180 dzianego, ze Ambrozy ay nauozaniu tak mocno akcentoral miare p Chrystusa. Na, niej, jak na dobrya Pundarenole, mo-

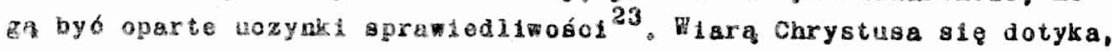

20 Expozit10 Evangel11 secundus lucam IX $66, \mathrm{SCh} 45,101$, PSP 16, 78 ; Por。 De 11 de V 12, 146, PL 16,077. W Fomatandach Ambrozego pystepuje tez temat Chrystusa jako Imporatora. Por. C. B.Charin, Chr18tus Imperator. Interpretazioni delia IV Scloga di Virgillo nell'ambiente di Sact"Amiorogio, "Rivieta di Storia e Letioratura Rel1glo8 an 8/1972/517 527.

21 Por nota 17; "Lforalta Magtoter" - chodal tu o neuczyciela moralnosci /Maglater morum/, albo po prostu o nauczyciola o nio-

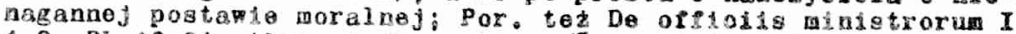

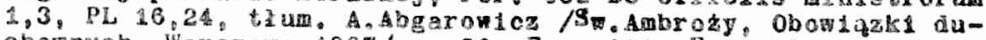
chownyoh, Varszawa $2967 /, 9.20$; Rxpositio kvangel11 seoundum Luean $i x$ 65; $X 232, \operatorname{SCh} 45,100, \operatorname{SCh} 52,200, \operatorname{PSP} 16,77,451$.

22 Expositio Evangel11 secundum Lucam IV 17; V 83, SCh 45,158 , 213, PSP 16,137,194。

23 Do opf1c118 mintatrorum I 29,142, PL 16, 84, Abgarowioz 69; Expositio Rvangol11 3ecundum Lucam VII 189, SCh 52,79, PSP 16,328. 
wiara Chrystusa sig widz1. Kresem wiary jest Syn Boga. Nalezy Go wyznawać otwarcie, a nie w sposób dwuznaczny. Nalezy wierzyó we wszystko, co Chrystusowi jest waściwe. Przede wazstkim, wbrew róznym herezjom, nalezy wo wierze przyjmowá́ równośó syna a ojcem 1 Duchem $S_{w} .24$ Ambrozy otwlerdzaz, ze wiara jest darem nadprzyrodzonym, zawdzlęczamy ja krzy zowl 1 krwi Chryetusa ${ }^{25}$.

Juz dawno przypigywano stoloyzm poglqdom moralnym Ambrozego ${ }^{26}$. Rzeczywiscie, "De offiolis ministrorum" wzoruje sie on niewatpliwio na Cyceronie. Jodnakze bardzo uwydatnia rótnioę mięay etyka pogańską a moralnośc1ą chrześc1jańska. Według sto1kón najwyzezym dobrem, dla którego nalezy wypeznlá́ obowiazki, jest sama cnota. Ambrozy zaś twierdzil, ze "pismo święte chce was widzleó ducha Syna Człowleczego, który przyszedł, aby zask udzielaé, a nie krzywdy wyrzadzać"27. Biskup Modiolanu u podstam moralności atamia wprawdzie nature, ale widz 1 ja perspektywle chrzesoljariskej zaski: naleźy uznawaó laske, alo nie zepoznawaó natury, chod laska przewyzaza nature ${ }^{28}$. Wodzug Ambrozego postawa zasadnioza uczniów Chryatusa winno byé naśladowante Go. Albowlem Jego Osoba 1 daialanio sa miaxa, która zyciu moralnym wezystko musi byó mierzono.

24 Exposit1o Evangel11 seoundum Lucam VI 57,93,101; X 87,155, SCh $45,248,263,266$, SCh $52,185,207$, PSP $16,231,245,249,436,458$; 0 koniecznosel wiary w równod́d Syna z Ojcem p1sal równiez Ambrozy $w$ "De f1de" IV 2,14-16, PL 16,620; Explanat1o Symbol1 3 , CSEL 73,4, POK 26,26; De Moteri1日 5,28, CSEL 73,100, POK 26, 42 .

25 Tamie, III 23, SCh 45, 132, PSP 16, 108.

26 Por. R, Thamin, Saint Ambroise et la morale au IV siéole. Etude comparée du traité "Des Devolra" do C1oeron et de saint Ambro1se, Paris 1895; G. Nosar 1, Del preteso sto1018mo C10eroniano nei libri"De offioilg" di'Saint'Ambrog10, Parma 1911; J.Draeseke, Ciceronis et Ambrosil "De offloilgh libri III inter 80 comparantur, "Rivistadi filologie"4/1875-76/121-164.

27 De offio1is mintstrorum I 28,131, PL 16,62, Abgarowioz 65.

28 Tamie I 46,222, PL 16,89-90, Abgarow1cz 99 ; Hexaemeron VI 4, 21 , PL 14, 249, PSP 4,196; De My Expositio Evangeifi secundum Lucam VII 201; VIII 32 , $\operatorname{sch} 52,84$, 113 , PSP $16,333,363$. 
3. "Eadem t1b1 qua Christus ambulavit gradiendum est via" 29

Biskup Mediolanu przypominaz czesto, ze Chrystus jest droga do 0jca. Dlatego waśnie stał sle człowlek1em, by nam utorowac droge do nieba, aby przez Niego rodzaj ludzki nauczyz sle 18 d́ drogami Pańskimi ${ }^{30}$. Jest więc Chrystus nie tylko drogą, ale 1 przewodnikiell. zycie na tej zieml Ambrozy porównywał do wędrówk1.

"Miejsce jest u Ojca, droga jest Chrystus... Idźmy ta droga, trzymajmy sie prawdy, podązajmy za zyciem. Wiara cie prowadzi, prawda cie umacnia, zyole od Niego ozywians1.

Kazdy ohrześcijanin musi być naśladowca Chrystusa - oto zasadnioze wyinaganie moralne, które bardzo często pojawia sie wismach św.Ambrozego. Być chrześcijanlnem jego zdaniom znaczy naśladować togo, który jest z natury Synem Bozym, a który przez Woielenie stax sie jednym z nas. Szczególnte częste wezwanla do naśladowania Chrystusa wystepuja na kartach jego "Komentarza do Ewangel11 ów. Lukasan", gdzie wielokrotnie wyjaśniaz, it za Chrystusem 1 dzie sle nie krokami ciała, lecz mzniostymi czynami:

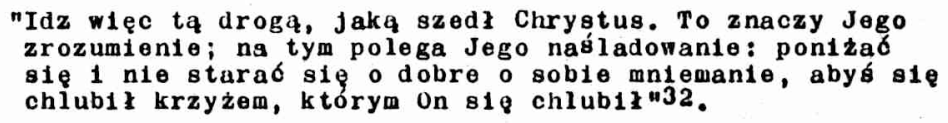

Wszyscy mamy sie upodobniac do Chrystusa, bo tylko On jest carkowitym obrazem Boga. Równiez kazdy sprawiedliwy człowiek upodabnia ele do tego Obrazu, jeśli gardzi świetem 1 lekceważy ziemskie irzyjemności ${ }^{33}$ :

29 Exposit1o Evangel11 secundum Lucam VI 100, SCh 45,266, PSP 16, 249.

30 De fide III 7,51 , PL 16,600; Hexaemeron I, 4, 15, PL 14, 129, PSP 4,41; Expositio Evangeli1 secundum Lucan II 45, SCh 45,93, PSP 16,70 .

31 De bono mortis 54, CSEL 31,1,739, PSP 7,166.

32 Expositio Evangel11 scundum Lucam VI 100, $\operatorname{SCh} 45,266$, PSP 16, 249; Por. tamze IV 12; V 41, SCh 45,156,198, PSP 16, 135, 179 .

33 Tanze, V 104; X 49, SCh 45,221; SCh 52,173, PSP 16,203,423. Tylko sam Chrystus wg Ambrożego moze bý nazwany "imago Dei" "Obrazem Boga" /Hexaemeron VI 7,41, PL 14,257, PSP 4,212/, czio- 


\begin{abstract}
mJesteśmy pod panowaniem Chrystusa, kledy oddajemy się pracy i uczynkom, kiedy naśladujemy postać sługi, którą On proyją, gdy sie wyniszczyłn34.
\end{abstract}

Wcielony Syn Bozy jest wzorem doskonałym z racj1 doskonałosc1 swej śwlętośc1. To wzór, który możemy naśladować, gdyź przez wcielenie stal się jednym z nas, biorac na siebie nasze słabości oprócz grzechu. Co więcej, Chrystus nie jest dla nas wzorem odległym. Winniśmy Go nálladowá zwłaszoza w clerpliwośc1 1 m znoszeniu krzywd. Ambroży ma wielkie nabożeństwo do Chrystusa umęczonego 1 ukrzyźowanego, którego bardzo często stawia za wzór. Gdy Mu złorzeczono - nie złorzeczył, gdy Go bito - nie uderzył, gdy Go obdzierano z szat - nie opleral sie, gdy Go krzyzowano - dla swoich prześladowców prosiz o przebāczenie. Chciał być opuszczony 1 zdradzony, aby 1 chrześcijanin, zdradzony przez swego towarzysza, zniós: to ze spokojem. Skoro Chryetus przebaczyl prześladowcom 1 Jego uczeń winien przebaczá ซyrządzone zniewagi. Naśladowanie Chrystusa polega bowiom na tym, abyśmy wraz $z$ Nim umierali。 Od Niego mamy sie nauczyc, jak poizonywać smutek przyszłej śmierci ${ }^{35}$. To silne akcentowante męki Zbavioiela nasuwa myśl, ze w pismach Ambrozego mamy pewnego rodzaju antycypacje średniowlecznej poboźnośc1 pasyjnej. Rozwazanie megki jest moralnym bodźcem naśladowanla 1 milowania Zbawiciela.

Biskup Mediolanu uezył nie tylko ogólnie, ze należy naśladozać Chrystusa, ale ukazywał szczegółowo, w jakich dzledzinach jest on wzoreil dla chrześcijanina. Najbardziej eksponowat pokorę, której Chrystus dak wzór. On stał sle mistrzem pokory, usługująo вжym uezniom. Pokora wiernyoh winna byó szczera, nie sztuczna, nie udawana ${ }^{36}, S_{w}$. Ainbroży zachęca:

wiek zaś jest tylko "ad imaginer", czyll posiada w sobie tylko coś z tego obrazu /por. Expositio'in Psalmum 118,10,16, CSEL 62,212; De Pide I 7,53 , PL 16,540; A.Santorsk1, Odkupien1e czlowieka, art.cyt. 361 .

34 De Plde V 12,151, PL 16,678; Expos1tio Evangel11 secundum Lucam $V 16, \operatorname{SCh} 45,188, \operatorname{PSP} 16,169$.

35 Ixpositio Evangel11 secundum Lucam V 45177 ; VI 34; VIII 24; $\operatorname{IX} 10 ; \mathrm{X} 56, \operatorname{SCh} 45,188,212,241$; $\operatorname{SCh} 52,110,144,175$, PSP 16 , $180,192,223,359,394,426$.

36 Rp1stola 2,18, PL 16,884; Exposit10 Evangel11 secundum Lucam V, 5184 ; VIT $59 ; X 51, \operatorname{SCh} 45,184,213, \operatorname{SCh} 52,28,174, \operatorname{PSP} 16,165$, $194,275,424$ 。 
"Niech nikt w tym zyciu nie pragnie błyszczeć, niech nikt nie rości sobie żadnych pretensji, niech nikt sie nie chełp1. Chrystus nie ubiegal sie tutaj o sławe, nio chciał, zeby w Ewangeli1 wychwalano Jego imie, dopóki przebywal na zlemi. Przyszedł, aby ukryć się przed tym śwlatem. I my więc $w$ podobny sposób ukryjmy zycie nasze na wzór Chrystusa, unikajmy chełpliwości, nie oczekujmy pochwal. Leplej zy tu pokorze, aby tam chwais osiegnacen 37

Ambrozy pragną wiernych zachęc1ó takte do praktykowania posłuszeństwa, miłosierdzia 1 ubóstwa za wzorem Zbawiciela ${ }^{38}$. Gzosił, ze trzeba ubogich ratować od głodu 1 wspleraś w niedostatku. Na tym bowiem polega upodobnienie sie do Chrystusa, zeby cudzego nle poząać 1 niczego nie zabierać bliźniemu celem przywłaszozenia sob1e 39 . Czytajac tego typu wypowiedzi Ambrozego, trzeba uświadomic sobie, ze pisaz je czasach niespokojnych, gdy toczyły sie wojny 1 wielo było nędzy oraz głodu, gdy lstniał wyzysk 1 nierówność społeczna.

Przykład Chrystusa dotyczył téz modlitwy. Komentując Pakt, ze Chrystus speqził noc na modlitwie, Ambrozy stwierdzał: "Lasz tu ukazany Jego czyn 1 masz wzór, Jaki winteneś naśladować. Co bowiem sam dla swego zbawienta czynić wintenes, skoro dla ciebie Chrystus spędza noc na modlitwie? Co masz czyní, jeśli choesz podją́ nykonanie jaklegoś poboznego zamiaru, skoro Chrystus maj zc rozesłać apostolow, modlil się 1 to sam sie modlił?"40 Biskup Mediolanu mów11 tez o poście Chrystusa, który przez swój przykład chcial nas pouozyé, jak nalezy zwalczać ponęty zaysłowe 41 .

Piegkne zdania wypowiadal Ambrozy na temat przyjaźni. Chrys-

tus :

"dał nam wzór przyjaźnł do naśladowanta, abyśmy spełniali wole przyjaciela, abysmy wyjawiali przyjacielowi wszystkie tajomice serca sivego 1 tak samo dobrze znali jego sekrety.

37 De offici1s ministorum III 5,36, PL 16, 156, Abgarowicz 177.

38 Epistola 63,87, PL 16,1213; Expositio Bvangel11 secundum Lucam V 42178 , SCh 45, 199,211, PSP 16,179,193.

39 De offici18 ministrorum I 30,151; III 3,15 , PL 16,671149 , Abgarowicz 73,169; Exposit1o Evangel11 secundum Lucam IV 34 , $\operatorname{SCh} 45,164, \operatorname{PSP} 16,143$.

40 Expositio Evangeli1 secundum Lucam V 43, SCh 45, 199, PSP 16, 180; Por. tamże, V 10, SCh 45,186, PSP 16,166.

41 Epistola 63,15, PL 16,1193; Expositio Evangel11 secundum Lueam 


\begin{abstract}
Otwierajmy przed nim serce nasze, a on przed nami swoje. "Nazwałem was przyjaciółmi - mówi Chrystus - albowiem oz najmiłem wam wszystko, co usłyszałem od 0jca mego" /J15, 15/. Niczego więc przyjaolel nie ukrywa, jesli jest prawdzinym przyjacielem, otwiera swe serce, jak to czyniz P.Jezus

z tajemnicami 0jca"42.
\end{abstract}

Idę naśladowania Chrystusa Ambrozy konkretyzował az do szozegółów, które dla nas są zrozumiałe tylko na tle ówczesnej sytuacji. Mimo prowadzonej przez cesarzy walki z pogaństwem, mimo wielu optymistycznych wypowiedzi ojców Kościoła o nawróceniu oałego świata, wielu jeszcze było pogan w cesarstwie. Sprawa usunięc1a z sal1 senatu ołtarza bogini Wiktori1 $382 \mathrm{r}$. przez cesarza Gracjana za namową Ambrozego jest dowodem, ze część senatorów mocno jeszcze broniła pogaństwa. Trzeba było a poganami ułozyé modus vivend1. Ambroży deklarował: Z tego, iz Pan je takze z grzesznikami, widá, ze nie zakazuje 1 nam z poganami zasiadać do stołu. Kto Idzie za Chrystusem, winien Mu dać plerwszeństwo przed pogańskimi rodzicami, gdyz wobeo religil ustępują obowiazki miłośl ${ }^{43}$. Biskup Mediolanu śwladom był roli, jaka spełnia zaska w naśladowaniu Zbariciela. "Nie możesz pójść za Chrystusem, jeśli on sam ciebie nie pociagnie ${ }^{44}$. To Chrystus jest głómnym sprawoa onoty człowieku.

4. "Prinoipium itaque nostrae virtutis est Christus" 45

W trzeciej księdze traktatu "De elide" Ambrozy wyraźnio przypominał, ze cnoty sa dokonywane $z$ woll 1 m mocy Chrystusa. On nie tylko jest wzorem cnót, ale jako Bóg jest początkiem wszystkiego 1 sprawca kazdej cnoty. Jest przeto poczatkiem czystości, okrom-

IV 4, SCh 45,152, PSP 16,130.

42 De officiis ministrorum III 22,136, PL 16,182, Abgarowicz 211.

43 Expositio Evangeli1 secundum Lucall V 18; VII 146, SCh 45, 189; SCh 52,63, PSP 16,169,309; Ambroży podkreślat, ze wzorująo sie na Chrystusie, należy czció rodziców. Por, tamzo, VIII 74, SCh 52, 133, PSP 16, 383 .

44 De Sacramentis V 2,10, CSEL 73,62, POK 26,81.

45 De fide III 7,52 , PL 16,625 . 
nośc1, clerpliwośc1, pokory. Od Niego bierze początek wszelka cno$t^{46}$. W "Komentarzu do Ewangel11 św.Lukasza" myjaśntająo znaczenie kwasu uczył, ze Chrystus jest kwasem, "bo podnosi czyjąs cnotę"47. Bez Niego nie moze istnieć zadna cnota. Co wiecej, bez Niego nie mog 11 by śmy się zbaw $1 c^{48}$.

Chcąc wyrazić czynną role Chrystusa wyolu moralnym wiernych Ambrozy uzywał różnych porównań. Jest więo Chrystus dobrym Ogrodnikiem, który troszczy się o to, byśmy przynosil1 owoce, bo bez Jego pomocy wzrost duchowy byłby niemozliwy. Gdzle jest Chrystus tam kwitna liczne cnoty. Tam, gdzie niewinność, czystość 1 poboznośd, tam sa Plołki wyznawców, lilie dziewic, róze męczenników ${ }^{49}$. Chrystus jest takze Lekarzem wozystkioh ludzi. On przyby na świat, aby oble płc1 uleczyć. Obecnie przebywająo w. niebie, równtez na ziemi lekarstw udziela. On tylko moze leczyó nasze rany duchowe. Nikogo jednak wbrew jego woll nie uzdraw $1 a^{50}$.

"Do Niego więc nieoh przyetapla wszyscy pragnący wyzdrowieć, niech przyjma lek, który lm przynísi od ojca... Z Bożego zrządzenia przyjąz ciało, by pokazać, ze prawo clata poddane jest prawu ducha"51.

Ambrozy nazywał Chrystusa takzo Samarytaninem. Jego nauka leczy rany 1 nakłania do skruchy. W Innym porównaniu Ambrozy mówit o Chrystusie jako sterniku. W duszy czlowieka ster przyjmuje Chrystus albo diabeł. Biskup Mediolanu lubił posługiwaó sie utartym diatrybio stoloko-cynickiej zestawleniem zycia doczesnego z morzem. Wezelkio

46 Tamze, III 6,44-45,49,51-52, PL 16,591,593.

47 Expositio Evangeli1 secundum Lucam VII 187, SCh 52,79, PSP 16, 327.

48 Tamze, V 20, $\operatorname{SCh} 45,190, \operatorname{PSP} 16,170$.

49 Tamze, II 76 ; VII $161125,128,180$, SCh 45,107 ; $\operatorname{SCh} 52,14,53$, 54,75 , PSP $16,83,260,300,301,323$.

50 De fido V 5,62, PL 16,662; Expositio Evangel11 secundum Lucam IV 57,61 ; V 27 , VI $50,69, \operatorname{SCh} 45,174,175,193,246,253$, PSP 16, $154,155,174,228,235$.

51 De Pide II 11,90, PL 16,579. Ambrozy nazywał Chrystusa nie tylko lekarzem, ale 1 lokarstwem na zio. Por. Expositio Evangelil secundum Lucam IX 27, SCh 52,150, PSP 16,400 . 
objawy wzburzenia morza, to obrazy zła na swiecie. Według niego to Chrystus jest sternikiem, ozuwajacym kazdy czas, by wzburzone fale tego śwlata nie przeszkodziły wezplecznym dotarciu do portu zbawienia ${ }^{52}$. Płyna po wzburzonym morzu:
"nle nalezy uszu zatykać, leoz je otwierać, aby móc usłyszeó głos Chrystusa. Kto Go przyjmie, ten nie begdzie obawial sie rozbicla. Nie bedzie potrzeba, Jak Ulissesa przywiazy- wać go do drzewa, lecz duch więzami duchorymi ma być przy- wiazany do drzewa krzyza, aby zmysłowo ponęty nim nie wstrząsały, zeby naturalne jego skłonności nie były nara- zone na rozbicie"53.

Aby zaś wyrazić konieczność wspópracy z Chrystusem w nabywaniu cnót áw.Ambrozy chętnie posługiwał się metaforami wojskowym1 1 sportomymi. Wozyscy, którzy sq wościele, sprawuja Boża zołnierke. Antychryst stara sie otoczyć dusze legionem swojego wojska. Biskupowi Mediolanu, który znal sie na sztuoe prowadzenia wojen, bliska była mý́l, żo Chrystus jest obrońca 1 s1łq w oblęzeniu dokonywanym przez wpływy świata. Chrześcijanin naznaczony "spiritale slgnaculum" $/=$ blerzmowanie $/^{54}$ ma męznie walczyć po stronie Chrystusa. Dostrzegał tez zgubne wpływy świata na zycie duchowe chrześciJanina. Zagadnieniu temu poświęciz dziełko "De ruga saeculi". Idealny chrześcijanin jest przez niego przedstawiony jake atleta Chrystuaa, który walczy, rozmyśla 1 ćwiczy sie w cnocie, umartwia się 1 jest szozęśliwy, ze walozy dla sprawy Bozej ${ }^{55}$. Z ldel chryatologicznych

52 De virginibus II 2,17, PL 16,211; De exoessu fratris II 5, CSEL 73,253 , POK 21,140-141; Epistola 35,12, PL 16,1080; De Incarnationis Dominicae sacramento 5,43 , PL 16,829, POK 26, 118-119; De Sacramentis III 1,3 , CSEL 73,38, POK 26,67; Exposit1o Evangel11 secundum Lucam VI $39, \operatorname{SCh} 45,242$, PSP 16,225 .

53 Expositio Evangeli1 secundum Lucam IV 2, SCh 45, 151, PSP 16, 130.

54 De Sacramentis III 2,8 , CSEL 73,42 , POK 26,69. "Spiritale signaoulum" w rzymsiej nomenklaturze wojskowej oznaczało złozenie przysiegl przez zolnierza, który odtąd mlał tatuaz na ręce lub nosiz ołowiany znaczek zawieszony na szy1. W słownictwie chrzesoijańskim uzywano tego słowa na okresiente chrztu, gdyz chrzest uważany byt za poczatek militiae Christi. De Helia 21,79, PL 14,726. 
Ambrozy wyprowadzal wnlosk1 nie tylko dla zycla moralnego; ale takze dla zjednoczenie mistycznego z Chrystusem, ucząc, zo dusza jest Jego oblubientoą.

\section{5. "Sposus an1mae secundum Verbum"56}

Mistyczna wié duszy z Chrystusem jako Oblubleńoem - Jak wykazal1 J.Marcel1c, R.Johanny 1 G.P1coolo - Jest Jednym z glównyoh tematów rozwazanych przez Ambrozego ${ }^{57}$. W wielu pismach omawia to zagadnienie, a szczególnie traktatach: "De Isaac et anima", "Explanat1o super Psalmos duodecim", "De Mysteri1s", "De Sacramentis", "De bono mortis", "De excessu fratris sul Satyri". Zjednoczenie duszy z Chrystusem zaczyna s1e juz na chrzcie, a Eucharystia jest uczta zaślubionych. 0 mistycznej lącznośc1 duszy z Chrystusem Ambrozy pisał szczególnie wiele w "Objaśnientu Psalmu 118", gdzie bardziej niz w Inych pismach, jest akcentowana prawda, 1z Chrystus jest źródłem 1 wzorem doskonałej milośol:

\footnotetext{
"Dusza sprawiedliwego jest oblubienica Slowa. Jé́ll ona pragnie szczerze, jeśli modli sie, a nodli sie wytrwale 1 pokornie, a cala uwage kieruje na słowo, wtedy wydaje się jej, te nagle słyszy głos Tego, którego nie widzi... czuje woble powlew 1 tchnience obecnośc1 Tego, którego szuka" 58 .
}

Chrystus przebywa tylkow duszach sprawiedliwych. Dlatego Ambrozy zachęcał:

"Otwórz twoje bramy Chrystusoni, by mógl do olebie wejód,
otwórz mu bramy sprawiedliwosiol, bramy czystosol, megtwa
1 madrości n59.

56 De Inoarnationis Dominicae Sacramento 5,35, PL 16,827, POK 26,116.

57 Por. J.Maroelio, Eoolesia Sponsa apud sanctum Ambrosium, Roma 1967, 89-102; B'. Johanny, Lo Eucharistie centre de lohistoire du alut chez saint Ambro1se de Milan, Paris 1968, 166-178; G.P10colo, Per lo studio della spiritualità ambrosiana. I sermoni "De Isaac vel an1ma", "Scuola Cattolica" 98"1970/ 32-74.

58 Expositio Psalmi 118, VI 8, PL 15,1337.

59 De Iide IV 2,19, PL 16,621; Epistola 63,4, PL 16,1190. 
Wlelk1 Doktor Mediolanu mówit tez niekiedy o przebywaniu $C_{\text {hrystusa }}$ " "sercu", a czasem w "duszy"60. W traktacie "0 Sakramentach" p1sał o zaślubinach Chrystusa z "duchem 1 dusza", przy czym chodziło mu tu o dwie cześc1 jednej duszy, zgodnie z fllozofia platońska /spiritus, anima/61. Wprowadził zaś to rozróznienie, aby podkréslió, ze cała istota ludzka 1 wszystkie tworzace ja elementy maja byó objęte zállubinami z Chrystusem.

Biskup Mediolanu lluatrowal tę nauke przez częste oytomante ksiegi "Pleśnl nad Pieśniami". Chogo zas oplead dobroozynne skutk1 relacjl oblubieńozej miedzy duszą a Chrystusem, postugiwat ole bibl1jnym obrazem wymlany pocałunków/Pp 1,1/, którym nadawat znaczenie duchowe. Zjednoczona z Chrystusem dusza:

"pozbywa sie wyuzdania win 1 ządz cielesnyoh. Jest z dala od ziemskich próznośc1; czuje Boza obecnó́d 1 laskę Bozego Słowa. N1epoko1 sie, gdy On późno przyohodz1. Zraniona mi-

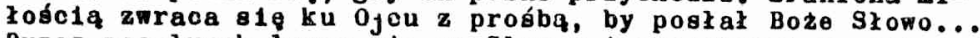
Przez pocalunek lazy sie ze Słowem 1 przechodzi na nie Duch tego, którego całuje"6̆.

Równiez słowas "Szczęśliwe sa te zaślublny, kiedy dusza poślubia Słowo a clało ducha"63 - sq zrozumiake tyhko wówczas, gdy uwzględnimy wytoj wopomniany podziaz duszy na częśc1. Trzeba tez zaznaozyó, ze oblubienica wystepujaca "Pieśnl nad Pieśniami" jest dla Ambrozego obrazem zarówno Kośctoła, jak 1 duszy ludzklej, 00 wyraza g1e u niego wielokrotnie powtarzająoym sie zwrooles "Eoolesia vel anima". Uozyz ponadto, ze Chrystus jako Słowo tez jest oblubleńcem duazy ${ }^{64}$.

60 De virginitate 19,123, PL 16,298; Epistola 41,12, PL 16,1116. De Spiritu Sancto 16,120, PL 16,805; De Saoramentio VI 2,6, CSEL T3,74, POK 26,87.

61 De Saerament 1s V 2,8, PL 16,467, POK 26,80; por. W. Se1bel, Fleisch und Geist beim hl.Ambrosius, Manchen 1958, 26-35.

62 De Isaac et anima 3,8, CSEL 32,647-648, PL 14,506; Por. Ep1stola 41,14-17, PL 16,1117-1118.

63 Expositio Evangelit secundum Lucam VI 9, SCh 45,231, PSP 16, 213.

64 De Incarnationis Dominicae Sacramento 5,35 , PL 16,827, POK 26, 116. Kazdy czlowiek według Ambrozego albo jest domem Boga albo diabla. Por, Expositio Evangel11 socundum Lucam VII 138, SCh 52,
138, PSP 16,306. 
Oplerajac sie na dorobku Orygenesa wypracowal Ambrozy teze, ze wercu wierzącego musi sie narodzió Chrystus, Jeśli Jego historyczne narodzenie w Betlejem nie ma być bezowocne. Komentujac Pakt macierzyístwa Mary 1 pisaz, ze co do ciała jedna jest tylko matka Chrystusa; jednakze co do wiary moze on urodzió sie wazdym. Kazda

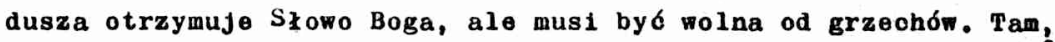
gdzie jest sprawiedliwość 1 mądrość, Chrystus rodz1 sie w serou ${ }^{65^{*}}$.
"A wigc 1 dla clebie, Jak dla Maryi, Słowo Boga niech wzrasta, niechaj w madrości 1 wioku czyni postepy. A stanie sie to, Jeśli wszystkie słowa sprawiedliwośc1 strzec będziesz w sercu swolm 1 nie b̧̨dziesz czekała starości, lecz poślubiwszy we wczesnym wieku spraw1e- dliwego męźa, bez uszkodzenla swogo clała, szybko pocz- niesz, szybko porodzisz, szybko karmíc będz1esz"66.

Ambrozy móvil tez o noszeniu Chrystusa w duszy. On, jako mistyczny Jeździec, chcial zasiąśc w ukryciu wnętrza dusz naszych 1 rzadzí krokami naszego ducha oraz poskramiać żądze ciała:

\footnotetext{
"Naucz się chętnie poddawaó su grzbiet twego ducha. Naucz się być pod Chrystusem, abyś nógł ponad świat 81ę พynieśó. N1e kazdy łatwo niesie Chrystua"67.
}

Biskup Mediolanu wyprowadzał jeszcze dalsze wnioski z tezy, ze dusza jest oblubieniog Chrystusa. Człowiek, posiadajao miłość oblubiencza, winien uznać, ze Chrystus jest dla niego wszystkim.

6. "Omnia Christus est nobis" 68

Ambrożego możnaby nazwać głosłclelem nabozeństwa nie tylko do Chrystusa wcielonego, ale przede wszystkim do Chrystusa Odkupi-

65 De virginitate 4,20, PL 16,271; Ep1stola 70,16, PL 16,1238; Expositio Evangeili secundum Lucam II 26,$38 ; \mathrm{X} 25, \operatorname{SCh} 45$, 84,89 , SCh 52,165 , PSP $16,60,66,415$.

66 Expositio Evangelif secundum Lucam $\mathrm{X} 32, \mathrm{SCh} 52,167$, PSP 16, 417.

67 Tamże, IX 11, SCh 52,144, PSP 16,395.

68 De virginitate 16,99 , PL $16,291$. 
ciela. Owocem Jego przyjócla na śwlat 1 smlerc1 na krzyzu było zycie wierzacych. W Komentarzu do Psalmu 36 pisal powtarzajac prawie litanijnie:

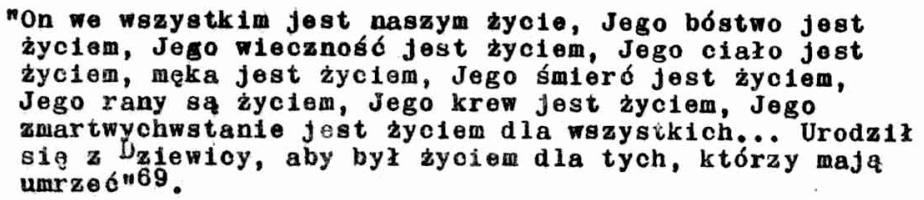

Równlez "Komentarzu do Ewange111 św.Lukasza" bardzo często przypominał, ze Chrystus jest naszym zyoiem 70 . Ten, kto sie Go trzyma, zginąó nie może, ten zaś, kto nie uwierzył whrystusa, jest duchowo martwy. Poganie, gdy uwierzą, dzięki lasce otrzymaja zycio. Jeśli nie chcemy sie lęká śmierci, musimy trwać przy Chrystusio ${ }^{71}$. Nazywająe Chrystusa zyciem, Ambrozy wyjaśniał, ze 1stnieja trzy rodzaje śmlerc1: naturalna, spowodowana grzechem 1 dla grzechu. W tym ostatnim rodzaju śmierei zyje sie dla Boga72. Uważal, ze gdzio jest Chrystus tam jest Jego raska 1 Jego nauka, odpuszczenie grzechów 1 wazystie wartości nadprzyrodzone. Chrystus bowiem stał oie wazyatkim dla nas ${ }^{73}$. W jego traktacie "O dziewictwie" mamy pięrne sformuŁowania, które sá dobrą 1lustraoja do słów Chrystusa: "Beze mnie nio uczynié nie mozecie" /J 15,5/:

"Wszystko mamy w Chrystusie. Niech sie do Niego kazda dusza zbliza: czy gdy choroba jej sa grzechy ciala, ozy gdy ja rania gwó́dzie ządz śwlatowych, czy kledy joszcze jest niedoskonala, lecz wozmyślaniu éwicząc sie usilnie,

69 In Psalmum 36,36, PL 14,985.

70 Por, Expositio Evangel11 secundum Lucam II 86; III 25; V 116; IX $2 ; X 121, \operatorname{SCh} 45,113,133,227, \operatorname{SCh} 52,141,196, \operatorname{PSP} 16,89,110$, $209,392,446$.

71 Tainze, VI 42; VII 2, 235, SCh 45, 243, SCh 52,9,96, PSP 16, 226, 254,346 .

72 Tamże, VII 36-38, SCh 52,21, PSP 16,267-268.

73 spistola 4,4, PL 16,890; Expositio Evangel11 secundum Lucam IV 6 , SCh 45,152, PSP 16,131; Por. G.Cerian1, La spiritualità d Sant'Ambrogio nel XVI centenario della nascità, Milano 1940,162167. 
mclaz postępuje; czy kiedy doskonała 1 w cnoty zasobna: bo kazda dusza jest we wadzy Pane, a Chrystus jest nam wszystk1m. Jeál1 ranę ulecqyó pragniesz, on lekarzem. Jeśl1 gorączka cie trawi, On źródiea, Jeśli cl olaży nieprawość, On sprawioditwoŕcia. Jeśli pomooy azukasz, on of jest moca. Jeśli śmierc1 się lękasz, on zyciem. Jeśli tęsknisz za nieber, on droga. Jeśli z kregu ciemności uc1ekasz, On śwlatiem. Jesili szukasz pokarmu, on chlebem"74.

Majac takio pojęcie roli, jaka Chrystus odgrywa w zyoiu wierzacego, Ambrozy równiez zat̂o uzasadnlaz konlecznośó modlitwy, która jego zdaniem jest rozmową z Chrystusem ${ }^{75}$. W szozegóiny sposób podkreślal on znaczente Modlitwy Pariskiej, dejac jej zwiezły 1 treściwy komentarz ${ }^{76}$. Często także zachęez skyoh duchownych do modlitwy: sał rómnlez nierzadko gryoh dzlelach graoal sio w modlitwie do Chryatusa ${ }^{77}$.

Przytoczone mypowledzl áw.Ambrozogo wyratule potwierdzaja teze o chrystocentryzmie zycia moralnego. Kledy się dzí́ móli o chryatologioznej "koncentracjd" toologil wapózczesnej, trudno jest nie dostrzogać, 12 pewnye sensie ozynit to jus sw.Ambrozy. To prawda, ż w jego mypowiedzlach jest wiele retaryki, ale ohrystocentryzm przejawta sio wyraźnte wo wazystich jego dzierach ${ }^{8}$. Gdybyśmy je prześledzllt worządku chronologloznym。 to zauwazylibyámy, w Jakim kierunku odbymata się ewolucja jego pogl३án ohrystologicz-

74 De virginitate 16,99, PL 16,29j, tłum, AoBober/Antologia patrystyozna, Kraków 1965/,167。

75 De offio118 ministrorum I 20,88, PL 16,50, Abgarowioz 50.

76 De Sacrament1s V 18-29, PL 16,469-474, POK 26,83-86.

77 Por. Mellegrino, Veni Domine Jesu, La preginiera al Signore Gesu in S.Ambrogio, w: Corona gratlarum, Miscellanea E.Deksers, Bruges 1975, t.1, 151-161.

78 Na chrystocentryzm doktryny toologlezned, moralnej 1 isteycanej Ambrozego zwracal rómiez uwage pawez VI w liścle do kard. Colombo "Grat18a1ma a not" / AAS 64/1973/647-6A9/ oraz womil11 - św. Ambrozym jako nauoycielu zycia chrzosoljalíkiogo "Qua veniamo" /OaRom 114/1974/ nr 283, 1-2/。 
nych. Poozatkowo bardziej akcentowal kwestie ścíle dogmatyczne, później zaś więcej interesomały go aspekty ascetyczno-mistyczne chrystologi1. Zawsze jedinak pozostawal moralista 1 zarówno z prawd doginatycznych, jak 1 mistycznych o Chrystusie wyprowadzał wniosk 1 praktyczne. Ambrozego trzeba ponadto uznać nie tylko za pośrednika miedzy teologia wschodnią a zachodnia, ale takze za prekursora średniowiecznej mistyki na Zachodzle. Przez swoja doktrynę o Chrystusie dał podstawy mistyki zachodniochrześcijańskiej, nieco odmiennej od wschodniej gnozy 79 , sformułowania zaś, których uzywał, zapowiadaja św.Bernarda, którogo zreszta one wprost inspirowały.

$$
\text { Ks. Antoni Młotek - Wrockaw }
$$

\section{CHRISTOLOGISCHE KONZENTRATION IN DER SITTENLEHRE DES HL.AMBROSIUS AUS MAILAND /Zusammenfassung/}

Wenn man die Schriften des hl. Ambrosius in chronologischer Ordnung untersucht, kann man bemerken, dass or originelle Lehre ther das geistige Leben des Menschen geschaffen hat. In dieser Lehre spielt der Christozentrismus eine wichtige loile. Éntschlossener Christozentrismus des Bischofs von Malland ist Érgebnis, u.a., seiner Kample mit den Heresien dieser Epoche. Nach der Lehre des hl. Ambrosius ist Christus Gott und Hensch zugleich, ein in zwei Wesen. Er 1st auch Sittenlehrer, der fur Ambrosius ein Vorbild 1st. Christus ist ftr thn Tdier aller Tugend, Liebenszlel der Seele, $18 \mathrm{t}$ fur uns alles. Den hl. Ambrosius kann man also als Praokursor des mittelalterlichen Mystizismus im Westen bezelchnen. Seine Formuliorungen, welche von $1 \mathrm{hm}$ in seinen Schriften gebraucht sind, sagen schon den hl. Bernhardus an.

79 F.H.Dudden, The Life and times of St.Ambrose, Oxford 1935, t, 2 ,676; L. Bouyer, La spiritualié du Nouveau Testament et des Péres, Paris 1966, 545 . 